
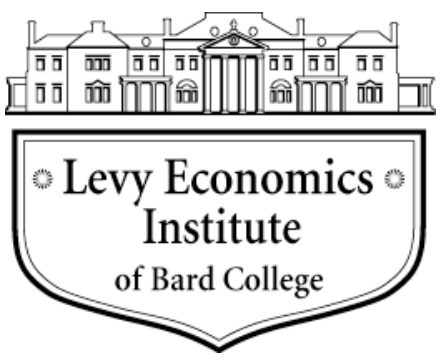

Working Paper No. 784

\title{
Financial Crisis Resolution and Federal Reserve Governance: Economic Thought and Political Realities
}

\author{
by \\ Bernard Shull \\ Professor Emeritus, Hunter College, CUNY \\ Adjunct Professor, Pace University \\ Special Consultant, National Economic Research Associates
}

January 2014

The Levy Economics Institute Working Paper Collection presents research in progress by Levy Institute scholars and conference participants. The purpose of the series is to disseminate ideas to and elicit comments from academics and professionals.

Levy Economics Institute of Bard College, founded in 1986, is a nonprofit, nonpartisan, independently funded research organization devoted to public service. Through scholarship and economic research it generates viable, effective public policy responses to important economic problems that profoundly affect the quality of life in the United States and abroad.

Levy Economics Institute P.O. Box 5000

Annandale-on-Hudson, NY 12504-5000

http://www.levyinstitute.org

Copyright (C) Levy Economics Institute 2014 All rights reserved 


\begin{abstract}
The Federal Reserve has been criticized for not forestalling the financial crisis of 2007-09, and for its unconventional monetary policies that have followed. Its critics have raised questions as to whom, if anyone, reins in the Federal Reserve if and when its policies are misguided or abusive. This paper traces the principal changes in governance of the Federal Reserve over its history. These changes have, for the most part, developed in the wake of economic upheavals, when Fed policy has been challenged. The aim is to identify relevant issues regarding governance and to establish a basis for change, if needed. It describes the governance mechanism established by the Federal Reserve Act in 1913, traces the passing of this mechanism in the 1920s and 1930s, and assays congressional efforts to expand oversight in the 1970s. It also considers the changes in Fed policies induced by the financial crisis of 2007-09 and the impact of the Dodd-Frank Wall Street Reform and Consumer Protection Act of 2010. It concludes that the original internal governance mechanism, a system of checks and balances that aimed to protect all the important interest groups in the country, faded in the 1920s and was never adequately replaced. In light of the Federal Reserve's continued growth in power and influence, this deficiency constitutes a threat not only to "stakeholders" but also to the independence of the Federal Reserve itself.
\end{abstract}

Keywords: Central Banks; Federal Reserve; Governance

\title{
JEL Classifications: E58, N2
}




\section{INTRODUCTION}

The Federal Reserve has been criticized for not forestalling the financial crisis of 2007-09, and for its unconventional monetary policies that have followed. ${ }^{1}$ Its critics have raised questions as to whom, if anyone reins in the Federal Reserve if and when its policies are misguided or abusive (i.e., questions as to governance).

This paper traces the principal changes in governance of the Federal Reserve over its history excepting its war-era commitment years to the Treasury. The changes have, for the most part, developed in the wake of economic upheavals, when Federal Reserve policy has, as recently, been challenged. The aim of this paper is to identify relevant issues regarding governance and establish a basis for change, if needed.

Section II briefly reviews the concept of governance. Section III describes the principal governance mechanism established by the Federal Reserve Act in 1913. Section IV traces the passage of this mechanism in the 1920s and 1930s; and congressional efforts to expand oversight in the 1970s. Section V considers the changes in Federal Reserve policies induced by the financial crisis of 2007-09 and the impact of the Dodd-Frank Wall Street Reform and Consumer Protection Act of 2010. Section V evaluates developments over time and their implications.

At its origin, Federal Reserve governance was principally instituted internally through a fragmented system that provided a set of checks and balances. The original arrangement eroded in the 1920s under the pressure of a new mandate for economic stabilization. Subsequent changes have left governance to external measures and, in particular, congressional oversight. External measures, however, have been limited. It is concluded that the absence of fully

\footnotetext{
${ }^{1}$ On Federal Reserve policies during the crisis, see Bernanke, 2012. For a critique of Federal Reserve monetary and regulatory policies leading to the crisis, see Financial Crisis Inquiry Report, 2011, pp. xvi, xvii. The Report finds that the housing bubble that precipitated the crisis was "fueled by low interest rates, easy and available credit, scant regulation, and toxic mortgages...." The Report notes "...the Federal Reserve's pivotal failure to stem the flow of toxic mortgages...." For a critique of Federal Reserve merger policy that over the previous 25 years had augmented the size of banking companies that proved "too-big-to-fail," see Shull, 2010. A number of economists have questioned the Fed's policies since the crisis in the public press, criticizing "centralized control by a few government officials." See Schultz, Boskin, Cogan, Meltzer and Taylor, 2012, p. A19. See also, Cochrane, 2012, p. A13, and Bhide and Phelps, 2013. A number of bills have been introduced in Congress to further reconsider and possibly alter Federal Reserve organizational structure and behavior. These include the "Sound Dollar Act of 2012," the "Federal Reserve Transparency Act of 2012," and the "Centennial Monetary Commission Act of 2013."
} 
effective governance poses a threat, not simply to "stakeholders," but to the independence of the Federal Reserve itself.

\section{GOVERNANCE}

Modern analysis of governance, particularly as applicable to corporations, developed over the past several decades. ${ }^{2}$ However, the conditions motivating governance have existed at least since the advent of the modern corporation that separated ownership from control. Today, governance mechanisms are deemed necessary for almost all large organizations to check the unlawful, opportunistic and otherwise misguided conduct of managers ("agents") that affect the welfare of those who have little if any influence over their policies and behavior (“stakeholders").

For private corporations, internal governance may reside internally in formal lines of authority, and in boards of directors; it includes external mechanisms and procedures, such as outside audits and, also, competitive markets for capital and control. Such mechanisms typically provide for some degree of transparency and accountability, often to an impartial governing body. It is generally recognized that governance constitutes an essential foundation for legitimacy. ${ }^{3}$

Independent government agencies are also subject to governance arrangements within a paradigm established in the late $19^{\text {th }}$ Century in the United States. In general, agencies such as the Interstate Commerce Commission (ICC), Federal Trade Commission (FTC), the National Labor Relations Board (NLRB) and the Securities and Exchange Commission (SEC) have extensive discretion in implementing laws through rules and regulations, and in formulating policies. Their policies and decisions were to be insulated from politics, with principal agency officials subject to removal only for cause. In recent years, most agencies have housed an Inspector General to review systems and practices aimed at preventing fraud, waste, abuse, and legal violations. Governance, in general, was to be exercised by congressional oversight.

The Federal Reserve System can, today, be classified as an independent agency of government. But there are differences that keep it more insulated than others, including selffinancing and the widespread conviction that detailed monitoring of its core function, monetary policy, by Congress or any other external body, would be damage the policy itself. Thus, audits

${ }^{2}$ Literature on the role of governance for private corporations is extensive. See, for example, Monks and Minow, 1995, Shleifer and Vishny, 1997, Gup (ed.), 2007.

${ }^{3}$ Monks and Minow, 1995, pp. 21-22 
by the General Accountability Office (GAO) have excluded monetary and related matters. Other governance mechanisms do exist, including internal audits, and external reviews by private accounting firms; the Board of Governors and Reserve Bank boards of directors monitor the Reserve Banks. An Inspector General also functions at the Board of Governors. But none of these measures are intended to govern the discretionary decision-making of Federal Reserve officials in monetary, regulatory and related areas.

\section{GOVERNANCE AT THE FEDERAL RESERVE'S ORIGIN}

After the panic of 1907 in the United States, it became apparent that a central bank, or something resembling one, was needed to mitigate financial upheavals. The banking community would have welcomed a privately-owned central bank, such as the Bank of England. It did welcome the Aldrich plan for a "National Reserve Association," effectively controlled by bankers. The Democratic party, in power at the time, rejected both as transferring Congress's constitutional authority "to coin money [and] regulate the value thereof,..." to private banking interests, believing doing so would increase the concentration of power in the hands of large Wall Street banking companies.

Another possibility was a central bank fully owned and controlled by the government. During the Bank War of the 1830s, Andrew Jackson had, at one point, considered a Treasury bank to replace the Bank of the United States. ${ }^{4}$ In 1913, about the time Congressman Carter Glass had a Federal Reserve bill he believed President Wilson would support, Treasury Secretary William MacAdoo proposed a central bank in the Treasury. Glass successfully opposed the proposal, knowing it would be unacceptable to bankers whose cooperation he believed was necessary. ${ }^{5}$

\footnotetext{
${ }^{4}$ Remini, 1967, pp. 59-60; Madeleine, 1943, pp. 45-48.

${ }^{5}$ The proposal was probably supported by Senator Robert Owens of Oklahoma, Secretary of State, Williams Jennings Bryan and Comptroller of the Currency John Skelton Williams (Link, 1956, pp. 205 ff). Glass reported that the proposal sent him into a spasm of hallucination in which he was tormented by the ghost of Andrew Jackson. Glass, 1927, p. 111
} 
The Glass-Owen bill finally adopted established the now well-known decentralized and fragmented System. ${ }^{6}$ The design, it has been said, embraced "the principles of federalism and democracy." "In addition to multiple, quasi-autonomous Reserve Banks, it provided representational authority for the major interest groups in the country. The Board was to include members, no more than one from any reserve district, with "fair representation of the financial, industrial and commercial interests and geographic divisions of the country," as well as the Executive branch through the Treasury Secretary and the Comptroller of the Currency. ${ }^{8}$ The Reserve Banks were to be overseen by boards of directors with nine members: three representing lenders (bankers), three representing borrowers (nonbankers engaged in "commerce, agriculture or some other industrial pursuit") and three public members (appointed by the Federal Reserve Board). ${ }^{9}$ The Board was expected to oversee and influence the operations of the Reserve Banks through the public members of their boards and, in particular, the public member selected as Chairman/Federal Reserve Agent. The Reserve Banks, in turn, were expected to have influence on the Board through a Federal Advisory Council made up of twelve bankers, one appointed by each Reserve Bank. Diversity and fragmented authority could be expected to produce a "clash of interests," and relied on to reduce the likelihood of objectionable policies. ${ }^{10}$ The checks and balances thus constituted a form of internal governance.

Backing up this arrangement, were limits on policy imposed by gold reserve requirements on deposit and note liabilities, Treasury audits of the Board and congressional oversight. ${ }^{11}$ Both the Treasury and Congress, however, would presumably be constrained by the aim to keep the System free of partisan politics. The Board, according to the House Report, was

\footnotetext{
${ }^{6}$ The House Committee Report stated that centralization “...is not necessary in order to obtain the benefits [of a central bank]...." (Changes in the Banking and Currency System of the United States, 1913, pp. 12, 28-30). On the relationship of the organizational form to National Reserve Association, see Wicker, 2005, pp. 92-93.

${ }^{7}$ Wicker, 2005, p. 94.

${ }^{8}$ As to the appointed Board members, Section 10 of the Federal Reserve Act provided (and still does) that “...not more than one...shall be selected from any one Federal reserve district, [and] the President shall have due regard to a fair representation of the different commercial, industrial and geographical divisions of the country...." The Board was not to include anyone currently engaged in banking.

${ }^{9}$ The boards were to appoint Reserve Bank officials, including a principal official to whom they gave the title "Governor."

${ }^{10}$ See Bopp, 1935, pp.11-12.

${ }^{11}$ Audit arrangements from the Federal Reserve's origin through 1975, are described by Governor George Mitchell in testimony before the House Subcommittee on Domestic Monetary Policy as reported in The Federal Reserve Audit Proposal, 1975, pp. 5, 6. Treasury auditing authority was transferred to the GAO when it was established in 1921, eliminated by the Banking Act of 1933 and restored for limited purposes in 1978. Also see Kettl,,1986, pp. $154 \mathrm{ff}$.
} 
to be "a distinctly nonpartisan organization and was to be wholly divorced from politics." 12 In fact, the House Committee Report indicated that Congress wanted as little to do with banking as possible. The Federal Reserve would allow “...the government...[to] be completely 'out of the banking business'...neither under the necessity of interfering with normal trade operations nor of artificially interposing to bolster up weak banks in any part of the country." ${ }^{13}$ Congress also hedged its bets by giving the Reserve Banks 20-year charters, a sort of probationary term identical to the charter durations for the First and Second Banks of the United States.

Whether or not this structural arrangement could produce good policy was moot. Paul Warburg, a principal author of the Aldrich plan, and an original member of the Board, saw it as a "system of checks and counter-checks - a paralyzing system which gives powers with one hand and takes them away with the other." 14 Almost two decades later, when significant changes in Federal Reserve structure were being debated, Karl Bopp, an economist who subsequently became President of the Federal Reserve Bank of Philadelphia, observed that the original System was a “...structure so complicated that a consistent long-run policy is scarcely possible."15

\section{THE PASSING OF MULTIPLE-INTEREST GOVERNANCE}

Between Paul Warburg and Karl Bopp much had changed. At its origin, System aims were limited, and the nature and extent of how it would function were uncertain. It was not even clear that it would operate continuously. In its First Annual Report, the Board felt obliged to state that Reserve Banks would do so in order to supervise banks, as well as providing an elastic currency in "extraordinary times." ${ }^{\prime 16}$ Congress, at the time, did not have the business cycle in mind. ${ }^{17}$

\footnotetext{
${ }^{12}$ See Changes in the Banking and Currency System of the United States, 1913, p. 43. The House Report also stated that "[i]n order...to guard absolutely against any suspicion of political bias.., it has been deemed expedient to provide in the law against a preponderance of members of one party." This provision was not included in the final legislation. The Senate bill also included a provision (struck out in conference) that not more than two members of the Board should be from the same political party. See Banking and Currency Bill, Comparative Print, 1913, p. 25.

${ }^{13}$ Changes in the Banking and Currency System of the United States, 1913, p. 30.

${ }^{14}$ Warburg, 1930, p. 166.

${ }^{15}$ Bopp, 1932, p. 379.

${ }^{16}$ Federal Reserve Board, Annual Report for 1914, p. 18.

${ }^{17}$ Irving Fisher's theory of "crises" had been laid out in The Purchasing Power of Money published in 1911.Wesley Claire Mitchell's seminal work, Business Cycles, was published in 1913. The business cycle was not mentioned in any of the thirty plus volumes of the National Monetary Commission, or in the reports of the principal congressional committees through which the Federal Reserve bill passed.
} 
By the early 1920s, however, both Congress and the Federal Reserve were alert to the cyclical performance of the economy and to the stabilizing role monetary policy could play. A new stabilization objective shattered the System's original internal governance arrangement. The next three sections trace changes following the financial upheaval of 1919-21, the depression of the 1930s, and the stagflation years of the 1970s. ${ }^{18}$

\section{Erosion after World War I}

Before World War I, the Federal Reserve had, in Benjamin Strong's words, been unable "to find a normal and natural place in the banking structure of the country." 19 It found a "place" during the war, supporting government borrowing. The Treasury's Annual Report for 1917 stated that without the Federal Reserve “...it would be impossible...to raise the... credits...to take care of the extraordinary expenditures entailed by our part in the war." 20

Continued support of Treasury financing following the war shackled monetary restraint in the face of inflation. Then, belated increases in Reserve Bank discount rates beginning in December of 1919 and into the spring of 1920 contributed to a sharp economic contraction and a precipitous decline in farm prices. Some critics called for Congress to limit Reserve Bank authority to raise discount rates without its approval. ${ }^{21}$

Post-war concerns about the farm sector had independently led Congress to establish a Joint Commission for Agricultural Inquiry. The Joint Commission added "the adequacy of credit resources"(Federal Reserve policy) to its agenda.

The Joint Commission held hearings on Federal Reserve policy in the summer of $1921 .^{22}$ The Federal Reserve's principal critic, John Skelton Williams, Woodrow Wilson's Comptroller of the Currency, claimed, among other things, that the Reserve Banks discriminated against rural banks, and that the Federal Reserve's policy mistakes stemmed from control by the large

\footnotetext{
${ }^{18}$ These three sections draw on Shull, 2005, Chs. 3-5.

${ }^{19}$ A quoted in Chandler, 1958, p. 101

${ }^{20}$ U.S. Treasury, 1918, p. 21; see also, Chandler, 1958, p.102. On the other hand, the Report of the American Economic Association's Committee on War Finance in 1918 objected to the policies that permitted the Treasury to sell securities at below market rates; arguing that the Treasury should have relied more on taxes. The Committee was chaired by E. R. A. Seligman and its members included E. W. Kemmerer, O. M. W. Sprague and H. Parker Willis, among others. On the Federal Reserve's rationale, see Strong to King, "Letter," 1922, pp. 1, 2.

${ }^{21}$ Meltzer, Vol. I, 2003, p. 127.

${ }^{22}$ Agricultural Inquiry, "Hearings," 1921.
} 
banking houses in New York. ${ }^{23}$ He called for the termination of all Board members from office on grounds of malfeasance and incompetence. ${ }^{24}$

The Joint Commission's Report in 1922 was mildly critical of the Federal Reserve. It deplored the delay in raising discount rates in 1919. We "...cannot excuse the action...in this period in failing to take measures to restrict the expansion, inflation, speculation and extravagance, ..." ${ }^{, 25}$ But, the Report also reflected the new awareness of "(b)usiness cycles of great prosperity and succeeding great depression, such as that from which we are now emerging...." ${ }^{26}$ In effect, its conclusions provided a warrant for monetary policy, independent of the Treasury, to aim at countering economic instability. The sensibilities of the day, as some Federal Reserve officials saw them, imposed a duty to do so. Adolph Miller, an economist and Board member, addressed a Joint Conference of Reserve Bank Governors and Chairmen in October 1921. He stated:

"The American people will never stand contraction if they know it can be helped. Least of all will they stand contraction if they think it is contraction at the instance, or with the consent of an institution like the Federal Reserve System,...The Reserve System cannot 'make' the business situation but it can do an immense deal to make its extremes less pronounced and violent....Discount policy...should always address itself to the phase of the business cycle through which the country happens to be passing.,"27

Stabilization policies, however, required coordination among the "clashing interests" that composed the Federal Reserve System. Open market operations, long understood but not previously utilized by the Federal Reserve for policy purposes, were initially coordinated in 1922 through a Reserve Bank committee organized by Governor Strong. ${ }^{28}$ This group became the Open Market Investment Committee the following year. With intent to make open market

\footnotetext{
${ }^{23}$ Some authorities have indicated that the Joint Commission was established in response to John Skelton Williams' attack on the Federal Reserve. See Kettl, 1986, p. 28 and Wicker, 1966, p. 55. However, according to Governor Harding, the charges made by Williams led the Board itself to request an investigation by the Senate Banking and Currency Committee; that Committee referred the matter to the Joint Commission, already established. The Commission, thereafter, included the Federal Reserve policy to the other issues it planned to investigate. See Harding, 1925, p. 219.

${ }^{24}$ As reported by Harding, 1925, p. 209.

${ }^{25}$ Report of the Joint Commission of Agricultural Inquiry, 1922, p. 15.

${ }^{26}$ Report of the Joint Commission on Agricultural Inquiry, pp. 11-12.

${ }^{27}$ Miller,1921, pp. 10, 11. See also, Federal Reserve Board, 1924, pp. $11 \mathrm{ff}$.

${ }^{28}$ Governor Strong's explanation of how open market operations began can be found in Stabilization, Part 1, Hearings, 1926, p. 309. For a discussion of the extent to which open market operations were understood as a policy tool prior to the 1920s, see Shull, 2005, pp. 90-93.
} 
operations effective and wary, after the political firestorm in 1920, of trying to restrict discounting by raising discount rates, the Board formulated new System-wide rules establishing a "reluctance-to-borrow," non-price rationing basis for Reserve Bank lending. ${ }^{29}$ New guides for policy were developed. ${ }^{30}$

Coordination in the 1920 s was far from perfect. ${ }^{31}$ But what was done provided a strong indication that, with economic stabilization as a goal, "checks-and-balances/clash-of-interest" governance was impracticable. Governance, if there were to be any, would be left to Congress.

As noted, the GAO took over for the Treasury in auditing the Board (but not the Reserve Banks) in 1921. Congress, itself, had already intervened through its Joint Commission in early 1922. From 1926 into 1928, the House Banking Committee held hearings on a bill and its variants requiring the Federal Reserve to promote stable prices. ${ }^{32} \mathrm{Had}$ it passed, it would have established a "rule" that would provide at least a partial substitute for the original, internal governance. ${ }^{33}$ It did not pass.

By 1927, in any event, Congress was sufficiently pleased with the central bank's performance to provide, in the Pepper-McFadden Act, Reserve Bank charters of indefinite duration to replace the 20-year charters it had granted in 1913. The Senate Report on the Act noted that " $[\mathrm{t}]$ he Federal reserve system has demonstrated its usefulness...and has been recognized throughout the world as the best banking system ever brought into existence."34

\footnotetext{
${ }^{29}$ The Reserve Banks had authority, provided by Section 14 of the Federal Reserve Act, to purchase and sell securities in the open market "under rules and regulations" of the Board. The Board indicated that they could do so "within the limits of prudence, as they might see fit." Federal Reserve Board, 1914, pp. 155-56. On the discount mechanism rules to accommodate open market operations as a policy tool, see Shull, August, 1971, pp. 33ff. ${ }^{30}$ Federal Reserve Board, 1924. With the major countries in the world off the gold standard, Adolph Miller also told the Joint Conference of Governors and Chairmen in 1921 that the gold reserve ratio was "almost worse than useless as a guide to changes in discount rates." Miller 1921, p. 14.

${ }^{31}$ Congress continued to give credence to checks-and-balances governance. In June 1922, it amended Section 10 of the Federal Reserve Act to increase the number of Board members from five to six in order to add a representative of agricultural interests to those already mentioned in the law. Conflict within the System continued through the decade with policy variations among Reserve Banks, and between Reserve Banks and the Board. The Board's influence on the Banks through the public members on their boards and, in particular, through the Chairman/Federal Reserve Agent was, it appears, largely frustrated (Bopp, 1935, pp. 11, 38, 46 ff.).

${ }^{32}$ Stabilization, Part 1 and 2, 1927 and Stabilization, 1928. The Senate bill in 1913 had contained a provision instructing the Federal Reserve to "promote stability in the price level" that, according to John R. Commons, George Shibley, a businessman and economics writer, had persuaded Senator Owen to insert [Commons, 1963 (1934), p. 64]. The provision was eliminated in conference (Willis, 1985 1923, pp. 1605-26; Fisher, 1928, pp. 22526). It was dropped, according to Commons, because President Wilson opposed it. It is of interest that Shibley was the first witness in the Stabilization Hearings in the House in 1926 on the amendment to the Federal Reserve Act, sponsored by James Strong of Kansas, that would have required "[a]ll of the powers of the Federal reserve system shall be used for promoting stability in the price level."

${ }^{33}$ See Fisher, 1934 and Commons 1925, p. 51.

${ }^{34}$ See National Bank Act, Report, 1926, p.14.
} 


\section{Restructuring in the Great Depression}

In the wake of the System's futility in the early 1930s, both economists and bankers made serious proposals to do away with privately-owned Reserve Banks. ${ }^{35}$ An initial congressional response in 1932 was to broaden the Federal Reserve's authority to extend additional credit. ${ }^{36}$ In 1933-34, congressional legislation strengthened the Board, by eliminating GAO audits, among other things. 37

By November 1934, the Roosevelt Administration under the direction of Marriner Eccles, newly appointed to the Board, was prepared to undertake a significant reorganization. In a memorandum to the President, Eccles had asserted that the System failed because (1) "the diffusion of power and responsibility" can result in "a complete stalemate;" and (2) the Governors of the Reserve Banks control open market operations and were "profoundly influenced by narrow banking rather than a broad social point of view." 38 He expressed concern that the Reserve Banks might sabotage Roosevelt's deficit financing plans. ${ }^{39}$ Roosevelt had similar concerns and considered, at one point, government ownership of the Reserve Banks ${ }^{40}$

Reorganization was undertaken in Title II of the Banking Act of 1935. Eccles proposed to reorganize the Federal Open Market Committee (FOMC) to include only Board members. He also proposed legislative language to make clear that each Board member represented the

\footnotetext{
${ }^{35}$ In 1933, a group of University of Chicago economists, including Frank Knight, Lloyd Mints, Henry Schultz, Henry Simons, Aaron Director and Paul Douglas, proposed government ownership of Reserve Banks (Kennedy, 1973, pp. 166-67). The Economic Policy Commission of the American Bankers Association proposed Reserve Banks be converted to branches of the Board (Burns, 1974, p. 82).

${ }^{36}$ The first Glass-Steagall Act in February 1932 and the Emergency Relief and Construction Act in July expanded the Federal Reserve's capacities to extend credit through open market operations and at the discount window.

${ }^{37}$ Among other things, the Banking Act of 1933 gave the Board authority to raise reserve requirements in emergencies and the sole authority over bank holding companies. It raised the salaries of Board members and lengthened their terms of office from 10 to 12 years. The Securities Exchange Act of 1934 gave the Board authority to establish margin requirements.

${ }^{38}$ Eccles, 1934.

${ }^{39}$ Eccles, 1934 and Eccles, 1951, p. 166, 187.

${ }^{40}$ See, Ickes, Vol. 1, 1953, pp. 108-09; and Schlesinger, Jr., 1959, p. 248. During the hearings on the 1935 Act Roosevelt responded (off the record) to a reporter's question about the possible government purchase of Reserve Bank stock by recalling that during the fight between Jackson and Biddle an advisor had suggested the government obtain a majority interest in the Second Bank. He observed "that...would have solved the banking situation...in a much more satisfactory way...during the next ten years..." A reporter then asked, did you say "next" or "last ten years." Roosevelt is reported to have joined in the laughter (Blum, 1959, p. 349).
} 
national interest, not regional or commercial interests (i.e., expressed "a broad social point of view ${ }^{41}$ ).

His proposals sparked controversy. Secretary of the Treasury Morgenthau initially opted for government ownership of Reserve Bank stock. ${ }^{42}$ But he objected to placing full authority with a Board that he believed had resisted cooperation with the Treasury. At the same time, he made clear that he did not want the System to be taken over by the Treasury. At one point he suggested the central bank be run by disinterested experts. ${ }^{43}$ Carter Glass objected to Eccles's proposals. He believed that Reserve Bank involvement in policy was necessary. Moreover, he argued, the System "was never intended...[to] be used as an adjunct of the Treasury...." 44

A central bank in the Treasury would, for good or bad, have resolved the governance issue. But neither Glass, who believed banker participation was needed, nor Morgenthau, were interested.

Title II of the Banking Act of 1935 was a compromise. The new Board of Governors constituted a majority, but not sole representation on the FOMC. In addition to definitive authority over discount rates, and new authority over reserve requirements, the Reserve Bank presidents selected by their directors were made subject to Board approval. ${ }^{45}$ In a gesture toward independence from the Treasury, something Glass had wanted, the Treasury Secretary and the Comptroller of the Currency were removed from the Board.

The old language of the law remained in the Banking Act of 1935, requiring that there be no more than one Board member from any one district, and urging that the President have due regard for diverse economic interests in his appointments to the Board. The Reserve Banks were still owned by their member banks, and their boards of directors were sustained in the original configuration. But under the chairmanship of Mariner Eccles, it was expected that the Board members, whatever their backgrounds, would focus on the national interest. Reserve Bank presidents were confronted by some ambiguity. They remained responsible to their diverse boards of directors, member banks and their regional districts; but the reorganization appeared to oblige them in their functions as FOMC members to place the national interest first. Eccles,

\footnotetext{
${ }^{41}$ The original wording he proposed was: "In selecting...members...the President shall choose persons...to participate in the formulation of national economic and monetary policies" (Bopp, 1935, p. 12).

${ }^{42}$ Blum, 1959, pp. 346-49.

${ }^{43}$ In addition to Blum, op. cit, see Banking Act of 1935, "Hearings," pp. 312-14; and Ickes, Vol. I, 1953, pp. 534-35.

${ }^{44}$ As quoted in Westerfield, 1933, pp. 727-28

${ }^{45}$ The titles of System officials and their terms in office were changed to emphasize the shift in authority from the Reserve Banks to the Board.
} 
nevertheless, continued to express concerns about Reserve Bank participation in policy. ${ }^{46}$ Wright Patman and subsequently others repeatedly proposed government ownership of the Banks. $^{47}$

The transfer of principal authority to the Board went a considerable distance to codify the centralization of the Federal Reserve initiated in the 1920s, and to memorializing the disintegration of checks-and-balances/clash-of-interest governance. Congressional oversight remained. But Eccles foreshadowed later chairmen by expressing concern about the intrusion of Congress into monetary policy, even given the elimination of GAO audits. ${ }^{48}$

\section{Congressional Oversight in the 1970s}

A long period of Treasury domination of the Federal Reserve, during and following World War II, ended with the Accord of 1951. The Federal Reserve reestablished independent monetary policy confident that interest rates need not change much to achieve desired results. It also decided to conduct open market operations principally in short-term treasury bills, intending to interfere as little as possible with other financial markets. Subsequent developments, including adaptive changes in financial markets and the oil crisis in the early 1970s disrupted this limited approach. By 1975, with unemployment rising to over 8 percent and inflation running at over 9 percent, monetary policy seemed confounded.

In 1975, Congress took steps to elevate its oversight. It explicitly asserted its constitutional authority in "House Resolution 133" of March 1975 (with the Senate concurring) to exert influence on both the Fed's monetary targets and strategy. The Resolution declared that the Board and the FOMC should: “(1) pursue policies...to encourage lower long term interest rates and expansion in monetary and credit aggregates appropriate to facilitating prompt economic recovery; and (2) maintain the long run growth...[of these aggregates] to promote...maximum employment, stable prices, and moderate long term interest rates." It called on the Board to consult with Congress at semiannual hearings about objectives and plans on the...aggregates in the upcoming 12 months. It concluded by stating that nothing in the

\footnotetext{
${ }^{46}$ Eccles, 1938 as reprinted in Weissman, 1973, pp. 142-44.

${ }^{47}$ See, for example, Government Ownership of the Twelve Federal Reserve Banks (1938).

${ }^{48}$ See Blum, 1959, p. 351.
} 
resolution should be interpreted to require specific growth or diminution in the aggregates if the Board and the FOMC determined that they cannot or should not meet these objectives. In such cases "they shall report to Congress the reasons...."49

The Federal Reserve Reform Act of 1977 established comparable statutory obligations in addition to requiring Senate confirmation for the presidential appointments of Chairman and Vice Chairman. Continuing the long retreat from the original internal governance, the Act also modified the character of Class B Reserve Bank directors. The new language required that they be "elected to represent the public" and "with due but not exclusive consideration to the interests of agriculture, commerce, industry, services, labor, and consumers [emphasis added]."

This line of congressional intervention culminated in 1978 with passage of the Humphrey-Hawkins Full Employment and Balanced Growth Act that established national objectives for full employment and price stability. Again, the Board and the FOMC were to establish monetary and credit aggregates consistent with national economic goals and Board Chairmen were to present semi-annual reports to the Senate and House Banking Committees on current conditions, prospects, and targets. Again, the Act provided that it should not be interpreted to require "objectives and plans with respect to the ranges of growth or diminution of the monetary and credit aggregates...be achieved if the Board of Governors and the Federal Open Market Committee determine that they cannot or should not...because of changing conditions." Heightened congressional oversight including the establishment of semi-annual reports and Hearings made the Federal Reserve more transparent. But their effectiveness as a method of governance remained problematic. ${ }^{50}$

In line with Congress's reformulation of its oversight responsibilities, the Federal Banking Agency Audit Act of 1978 restored GAO authority to audit the Fed. The authority now provided for audits of Reserve Banks as well as the Board. But, as noted, it excluded monetary policy and related areas. ${ }^{51}$

The Federal Reserve's efforts to extinguish inflationary expectations, beginning in October 1979, produced extraordinary interest rate volatility and widespread collateral damage.

\footnotetext{
${ }^{49}$ H. Con. Res. 133, March 24, 1975. See also The Impact of the Federal Reserve System's Monetary Policies on the Nation's Economy, 1976, pp. 49-50.

${ }^{50}$ See "Independence, Congressional Weakness and the Importance of Appointment" (2012), pp.1836-38; Meltzer, (2009), Vol. II, Bk Two, pp. 985-92; and Kettl (1986), pp. 149-50. For a statistical analysis of informal congressional influence on monetary policy through signaling, see Havrilesky (1995), Ch. 7.

${ }^{51}$ An Inspector General was also installed at the Board in accordance with the Inspector General Act of 1978. For additional limitations in accorded “independence," see The Budgetary Status of the Federal Reserve System, Congressional Budget Office (1985), pp. 12 ff.
} 
Bitter complaints emanated from farmers, the building trades and community groups. Academic criticism focused on Federal Reserve policy that had been too easy in the 1970s, and then reversed itself too sharply in the early 1980s. ${ }^{52}$ Milton Friedman found an underlying cause for the Federal Reserve's mistakes in its insulation from market constraints, elections and the normal government budgetary process; ${ }^{53}$ i.e., in the inadequacy of governance. Disappointed in its performance and its unwillingness to accept a monetary "rule," he proposed, at one point, that it might be made "either...a bureau in the Treasury...or...[placed] under direct congressional control." 54

\section{THE FINANCIAL CRISIS: DODD-FRANK MODIFICATIONS}

The restoration of relative interest rate and price stability after the early 1980s ushered in a period of sufficiently lowered volatility to be termed, by some economists, "the Great Moderation." 55 The Federal Reserve still had academic critics who, particularly early in the period, saw the organization's insularity and policy-making discretion, as a source of mismanagement and costly mistakes. ${ }^{56}$ However, as in other periods of relative economic stability, political concerns about Federal Reserve governance receded.

This remission ended with the financial crisis that began in 2007. With the onset of the crisis, the Federal Reserve undertook aggressive and innovative measures. It expanded access to its discount window for depository institutions, created new credit facilities for non-depository institutions, extended credit to permit the acquisition of large firms whose failures it believed would have systemic effects and expanded its assets through the purchase of long-term governments and mortgage-backed securities from about $\$ 700$ billion to near $\$ 4$ trillion currently. It fashioned new monetary tools by paying interest on reserves and through "forward

\footnotetext{
${ }^{52}$ See Friedman, February 1982.

${ }^{53}$ Friedman, February 1982, pp. 103, 114.

${ }^{54}$ Friedman, February, 1982, p. 118. For his earlier proposal for a "rule," see Friedman, 1962, pp. $242-43$.

${ }^{55}$ Bernanke has argued that improvements in monetary policy over that in the 1960s and 1970s was a principal underlying cause. See, Bernanke, 2004.

${ }^{56}$ The intensity of the criticism is manifest in Havrilesky, 1991 and Mayer, 1990, pp. 1-11.
} 
guidance." It's near-zero interest rate policy has affected credit and resource allocation in the course of stimulating both the real estate and stock markets. ${ }^{57}$

The Dodd-Frank legislation included measures that extended Federal Reserve authority and responsibilities, and also imposed some new controls and governance arrangements. In reorganizing agency responsibilities, it sustained Federal Reserve authority over bank holding companies and extended it to include large, systemically important non-bank financial institutions designated as such, by the newly established Financial Stability Oversight Council (FSOC) ${ }^{58}$ The FSOC, composed of the heads of all agencies with financial sector responsibilities, including the Board, is chaired by the Secretary of the Treasury and now has principal responsibility for monitoring and countering systemic threats.

Dodd-Frank has also modified Sec.13(3) of the Federal Reserve Act, prohibiting the Federal Reserve from targeting specific nonbank companies for rescue as it did during the financial crisis with AIG and Bear Stearns. It may still provide credit to "individuals, partnerships and corporations" (IPCs), in "unusual and exigent circumstances" but only within a "facility or program with broad-based eligibility." It must have Treasury approval for such programs, must consult with the Treasury as to policies and procedures, and provide reports to Congress. Dodd-Frank asserted further congressional oversight in the area of supervision by requiring the Board appoint a Vice Chairperson for Supervision who is to periodically report to Congress on supervisory and regulatory matters.

The law mandated increased transparency through a one-time GAO review of all loans and other transactions related to the Fed's emergency financial assistance during the financial crisis (December. 1, 2007 and July 21, 2010); the audit included an evaluation of the

\footnotetext{
${ }^{57}$ For an earlier view on the transmission of unexpected monetary policy effects through changes in stock market values, see Bernanke and Kuttner, 2004.

${ }^{58}$ All bank holding companies with assets in excess of $\$ 50$ billion that are, by the Act's definition, systematically important financial institutions (SIFIs). Factors applied by the FSOC in making such designations include a company's "scope, size, scale, concentration, interconnectedness...." In July, 2012, the FSOC designated eight "financial market utilities" (clearing or settlement systems) as systematically important. In July, 2013, it designated AIG and GE Capital as systematically important nonbank financial institutions. Subject to recommendations by the Council, the Fed is required to impose "enhanced prudential standards" on all SIFIs, including higher capital, leverage and liquidity requirements. SIFIs must also develop "orderly resolution" plans ('living wills') intended to permit their liquidation without systemic impact. The Federal Reserve and FDIC have jointly issued rules for "living wills." If a company does not submit a credible resolution plan, the Federal Reserve may determine that it "poses a grave threat to financial stability." On a two-thirds vote of the FSOC, it can restrict mergers, acquisitions, involvement with specific financial products, and require it to sell assets. In the case of a failed banking company, the FDIC can take the company into receivership so that it continues to function until sold.
} 
effectiveness of the policies, and was completed in $2011 .^{59}$ Periodic GAO audits, however, continue to exclude monetary policy and related areas.

These changes do not directly impact the Federal Reserve's core monetary authority. But the Federal Reserve has long considered supervisory and lender-of last resort authority as closely-related. ${ }^{60}$

One change was aimed at reducing the role of bankers in policy formulation. DoddFrank excluded banker-directors (Class A) from the selection process for Reserve Bank presidents. At most, the provision bolsters the final authority over Reserve Bank presidential selections the Board has had since the Banking Act of 1935.

The full impact of the expanded role of the Treasury, and to a lesser extent Congress, on monetary policy as the result of Dodd-Frank is, as yet, unclear. As noted above, there are, at present, a number of bills in Congress that would constrain Federal Reserve discretion in one way or another.

\section{DISCUSSION}

Review of Federal Reserve governance reveals the role of the System's original "checks-andbalances/clash-of-interest" design, the necessity for its early deconstruction, and the subsequent reorganization that shifted authority to the Board, obliging all policy-makers to focus on what Eccles termed "a broad social point of view" rather than parochial interests. These changes notwithstanding, much of the original System architecture has been retained, including continued member-bank ownership of twelve Reserve Banks, and legal language that specifies diversified economic and regional interests for policy-making officials.

The original internal governance mechanism was a crucial factor in Congress's intention to insulate the Federal Reserve from politics. Since the mechanism was crippled by System objectives that required centralization and coordination, Congress has struggled, with modest success at best, to establish an external substitute that would not interfere with the Federal Reserve's independence in formulating and implementing monetary policy.

\footnotetext{
${ }^{59} \mathrm{GAO}, 2011$.

${ }^{60}$ Board of Governors, 1984.
} 
Reorganization in the 1930s nested principal authority with a Board of Governors composed of presidential appointees, providing the Executive branch with more influence than it previously had. When monetary policy independence was restored in 1951, congressional oversight remained, but was relatively unobtrusive.

By the mid-1970s, however, recognition of the impact of monetary policy on economic conditions and Federal Reserve's fallibility, lead Congress to amplify its oversight. The measures Congress took thereafter increased transparency, but have done little to provide the protections promised by the original governance mechanism. ${ }^{61}$

Congressional oversight has been limited by the widely accepted belief, vigorously supported by the Federal Reserve, that monetary policy must be formulated and implemented independently. ${ }^{62}$ Federal Reserve resistance to external monitoring has been fortified by unusually long terms for Board members, as well as "for-cause removal restrictions," selffinancing and chairpersons who have become icons with financial market constituencies. Other external governance has been attempted. In 1929, and again in the 1970s, private suits invited court intervention into monetary policy decisions that the courts notably rebuffed. ${ }^{63}$

While governance has lagged, the Federal Reserve has grown in power and influence, principally in periods of economic disturbance for which its policies have born some responsibility. ${ }^{64}$ The period since 2007 is the most recent example.

A rationale for "failing upward" was articulated recently by Martin Feldstein in reviewing the financial crisis that began in 2007. "[T]he Federal Reserve," he observed, "deserves some of the blame...Fortunately it has learned from its past mistakes....[R]eforms that

\footnotetext{
${ }^{61}$ For a discussion of central bank transparency elsewhere in the world, see Crowe and Meade, 2007.

${ }^{62}$ Chairman Bernanke, in widely-reported testimony before House Financial Services Committee on July 18, 2012, responded to calls for full GAO audits by visualizing a "nightmare scenario" that would have Congress secondguessing monetary policy decisions as they were being formulated.

${ }^{63}$ A 1929 suit alleged that the Federal Reserve had spread propaganda concerning a shortage of money, restricted the supply of credit for investment purposes, and caused stock and bond prices to fall in value, thus depriving the plaintiff of property without due process of law. (Federal Reserve Bulletin, August, 1929, p. 566). The Circuit Court stated: "We can see no basis for the contention that it is a tort...even though...[Federal Reserve] policy may be mistaken and its judgment bad. The remedy sought would make the courts, rather than the Federal Reserve Board, the supervisors of the Federal Reserve System, and would involve a cure worse than the malady" Raichle $v$. Federal Reserve Bank, 34 F.2d 910, 915 (2d Cir. 1929). About 50 years later, a claim arising out of the Franklin National Bank failure was similarly decided: "(it) would be an unthinkable burden upon any banking system if...[Federal Reserve's policies] were to be subject to judicial review. Indeed, the correction of discount rates by judicial decree seems almost grotesque,..." Huntington Towers, Ltd. v. Franklin National Bank, 559 F.2d 863, 868 (2d Cir. 1978).

${ }^{64}$ For a discussion of the Federal Reserve's growth in periods of economic distress, see Shull, 2005, Ch. 6.
} 
are adopted now should aim to strengthen [its]...performance...rather than to reduce its powers." 65

The result is that an increasingly invasive monetary policy is formulated and implemented, as former Governor Lawrence Meyer observed, solely by nineteen Federal Reserve officials "known only to a minute percentage of our population-meeting regularly behind closed doors." ${ }^{\text {"66 }}$ None, to state the obvious, are elected.

This circumstance creates risks, not only for those affected by policy but for the Federal Reserve itself. Growth in power without effective governance, accompanied by increased transparency, tends to make policy mistakes more obvious and less acceptable to those adversely affected and their political representatives. More than forty years ago, Kenneth Boulding pointed out, interestingly in a Federal Reserve publication, that the determinants of legitimacy are non-linear and exhibit discontinuities. "Sometimes an institution, the legitimacy of which seems to be absolutely unquestioned, collapses overnight."67

Or there could simply be a continuation of the slow institutional drift toward Treasury superintendence. The FDIC Improvement Act (FDICIA, 1991) required approval by the Secretary of the Treasury (with agreement by the President) for Federal Reserve (and FDIC) bail-outs of large banking companies; i.e., the 'systemic risk exception. ${ }^{68}$ Dodd-Frank subsumed critical Federal Reserve supervisory authority to the FSOC, chaired by the Secretary of the Treasury.

Executive Branch influence over Federal Reserve policy in national emergencies, and sometimes in their absence, is nothing new. ${ }^{69}$ Given the state of governance, it is not only conceivable but reasonable in periods of economic distress and monetary policy misgivings for

\footnotetext{
${ }^{65}$ Feldstein, 2010, p. 143.

${ }^{66}$ Meyer, 2004, p. xi

${ }^{67}$ Boulding, 1971, p. 3

${ }^{68}$ FDICIA created a systemic risk exception to the general bar on "bail-outs," requiring a joint agreement of the Federal Reserve, the FDIC and the Secretary of the Treasury, with the agreement of the President.

${ }^{69}$ As early as 1922, Benjamin Strong recognized " [t] $]$ he natural inclination of the Administration...to exert every effort possible to make business good....[T] hat key is found in the Federal Reserve....In other words, again cheap money,..." "Memorandum," Strong to Snyder 1922, pp. 2,3. Presidential influence to reduce the discount rate through appointments and informal contacts was evident in the 1920s (Bopp, 1935, pp. $12 \mathrm{ff}$.). Also see, Shull and Jacques 1995-96, pp. 227-30. For anecdotal reports on specific episodes, see Bremner, 2004, pp. 205 ff.; Ferrell 2010; Maisel 1973, pp. 108 ff. and pp.146 ff.; and Silber, 2012, pp. 254 ff. For evidence of effective Federal Reserve resistance to presidential intervention, see "Independence, Congressional Weakness and the Importance of Appointment," 2012, pp. 1837-38.
} 
the Treasury to take on traditional System functions, moving it toward the kind of central bank that Andrew Jackson considered, William McAdoo proposed, Franklin Roosevelt suggested might solve the problems of his day, and even Milton Friedman was willing to contemplate.

It is obvious that the pressures that accompany external governance could undermine the independence of the Federal Reserve. It is, perhaps, less obvious that the absence of effective governance, particularly with a System that has become increasingly influential and invasive, can do the same.

There is now a stark contrast between the intricate counterweights that Congress established in 1913, when it transferred modest discretionary authority over money and credit to the Federal Reserve, and the murky external governance that exists today for the immeasurably more powerful institution. Their deficiencies aside, an attractive feature of a "rule" for monetary policy as supported by economists such as Irving Fisher and John R. Commons in the 1920s, Milton Friedman in the 1960s and, more recently, John Taylor is that it resolves the governance issue. Absent a rule, the challenge to the Federal Reserve's stakeholders (that includes just about everyone) and the Federal Reserve itself are to find a substitute for the "checks and double checks" that Paul Warburg decried 100 years ago.

\section{CONCLUSIONS}

Federal Reserve governance was, at its origin, principally instituted through a fragmented system that provided an internal set of checks and balances. The original arrangement eroded in the 1920s with policies aimed at smoothing out the business cycle. Governance was left to congressional oversight, limited by the general view that monetary policy should be insulated from politics

Reorganization of the Federal Reserve in 1935 shifted authority from the Reserve Banks to the Board and codified the change from a fragmented system to a centralized organization. Congress, in the 1970s made an effort to assert its constitutional prerogative to both monitor and alter Federal Reserve policy, but its influence has been limited.

With the dissolution of internal governance and limited external governance, the inexorable expansion of the Federal Reserve's power and influence, largely in periods of economic distress, has intensified the need for effective governance. The absence of adequate mechanisms remains a threat, not only to those affected by monetary policy, but to the independence of the Federal Reserve itself. 


\section{REFERENCES}

Agricultural Inquiry, Hearings before the Joint Commission of Agricultural Inquiry, 1921, $67^{\text {th }}$ Cong., $1^{\text {st }}$ Sess., Senate Concurrent Resolution 4, Part 13, U.S. G.P.O., Washington, August 1-11.

Alvarez, Scott G. and Thomas C. Baxter Jr., 2011, "Federal Reserve Lending Disclosures," Testimony before the Subcommittee on Domestic Monetary Policy and Technology, Committee on Financial Services, U.S. House of Representatives, Washington, D.C. June 1 .

Bernanke, Ben S., 2012, "Monetary Policy since the Onset of the Crisis," Speech at Federal Reserve Bank of Kansas City Symposium, Jackson Hole, Wyoming, August 31.

Bhide, Amar and Edmund Phelps, 2013, Wall Street Journal, “Opinion,” July 16, WSJ.com

Banking Act of 1935, Hearings before a Subcommittee of the Senate Committee on Banking and Currency, $74^{\text {th }}$ Cong., $1^{\text {st }}$ Sess. on S 1715 and H.R. 7617, April 19-June 3, 1935.

Banking and Currency Bill, 1913, Comparative Print as Passed by the House, by the Senate and as Agreed to in Conference, H.R. 7837, U.S. Senate Doc. 335, 63 ${ }^{\text {rd }}$ Cong., 2d Sess. U.S. G.P.O., Washington.

Bernanke, Ben S., 2004, "The Great Moderation," Remarks at the Meetings of the Eastern Economic Association, Washington, D.C., February 20, 2004

Bernanke, Ben S. And Kenneth N. Kuttner, 2004, "What Explains the Stock Market's Reaction to Federal Reserve Policy?" Working Paper 10402, http://www.nber.org/papers/w 10402, National Bureau of Economic Research, Cambridge, MA. March

Blum, John Morton,1959, From the Morgenthau Diaries: Years of Crisis, 1928-38, HoughtonMifflin Co., Boston, Mass.

Board of Governors of the Federal Reserve System, 1984, "The Federal Reserve's Position on Restructuring of Financial Responsibilities," Federal Reserve Bulletin, July, pp. 547-57

Bopp, Karl, 1932, “Two Notes on the Federal Reserve System, The Journal of Political Economy, Vol. XL, No. 5, June, pp. 379-391.

Bopp, Karl, 1935, "The Agencies of Federal Reserve Policy," The University of Missouri Studies, Vol. X, No. 4, October 1. 
Boulding, Kenneth E., 1971, “The Legitimacy of Central Banks,” Reappraisal of the Federal Reserve's Discount Mechanism, Volume 2, Board of Governors of the Federal Reserve System, Washington D.C., August, pp. 1-13.

Bremner, Robert P., 2004, Chairman of the Fed, Yale U. Press, New Haven,

The Budgetary Status of the Federal Reserve System, 1985, Congressional Budget Office, February.

Burns, Helen M., 1974, The American Banking Community and New Deal Banking Reforms: 1933-1935, Greenwood Press, Westport Conn.

Central Bank Governance and Financial Stability, 2011. Report by a Study Group, Bank for International Settlements, May

Chandler, Lester V.,1958, Benjamin Strong, Central Banker, The Brookings Institution, Washington D.C.

Changes in the Banking and Currency System of the United States, 1913, House Report No. 69, 63d Cong., 1st Sess., September 9.

Cochrane, John B., 2012, "The Federal Reserve: From Central Bank to Central Planner," Wall Street Journal, September 1-2, p. A13.

Commons, John. R. 1963 (1934), Myself, University of Wisconsin Press, Madison, Wisconsin, . 1925, "The Stabilization of Prices and Business," American Economic Review, Vol. XV, March.

Crowe, Christopher and Ellen E. Meade, 2007, "The Evolution of Central Bank Governance around the World," Journal of Economic Perspectives, Vol. 21, No. 4, Fall, pp. 69-90.

Eccles, Marriner, C., 1951, Beckoning Frontiers, Alfred A. Knopf, New York.

. 1938, "Statement" at Hearings before House Committee on Banking and Currency, April 12-13, 1938 as reprinted in as reprinted in Economic Balance and a Balanced Budget, Public Papers of Marriner S. Eccles, R. L. Weissman (ed.), DaCapo Press, New York, 1973, pp. 142-44.

1934, "Desirable Changes in the Administration of the Federal Reserve System," Memorandum Given to President, 11/3/34, Reproduction in Roosevelt Papers, Franklin D. Roosevelt Library, Hyde Park, N.Y.

Economic Policy Commission, "Report," American Bankers Association, April 10-12, 1933

Federal Reserve Audit Proposal, 1975, American Enterprise Institute, Washington, D.C. .

Federal Reserve Board, 1929, Federal Reserve Bulletin, August, 1929, Washington D.C. 
. 1924, Tenth Annual Report for 1923, Washington D.C., GPO.

. 1923, Ninth Annual Report for 1922, Washington D.C., GPO

. 1915, First Annual Report for 1914, Washington D.C. U.S. GPO

Feldstein, Martin, 2010, “What Powers for the Federal Reserve?" Journal of Economic Literature, Vol. 48, No. 1

Ferrell, Robert H., 2010, Inside the Nixon Administration: The Secret Diary of Arthur Burns, 1969-74, University Press of Kansas, Lawrence, Kansas.

Financial Inquiry Commission, 2011, The Financial Crisis Inquiry Report, Final Report of the National Commission on the Causes of the Financial and Economic Crisis in the U.S., Pursuant to Public Law 111-21, January

Fisher, Irving, 1911, The Purchasing Power of Money: Its Determination and Relation to Credit, Interest, and Crises, Macmillan, New York.

. 1928, The Money Illusion, Adelphi Co., New York.

. 1934, Stable Money: A History of the Movement, Adelphi Co., New York.

Friedman, Milton, 1982, "Monetary Policy: Theory and Practice," Journal of Money, Credit and Banking, Vol. 14, No. 1, February, pp. 98-118.

. 1962, "Should There Be An Independent Monetary Authority," In Search of a Monetary Constitution, (Leland B. Yeager (ed.), Harvard University Press, Cambridge, Mass.

GAO, 2011 Federal Reserve System: Opportunities Exist to Strengthen Policies and Processes for Managing Emergency Assistance, GAO-11-696, Jul 21.

Glass, Carter, 1927, An Adventure in Constructive Finance, Doubleday, Page \& Co., New York.

Government Ownership of the Twelve Federal Reserve Banks, 1938, Hearings before the Committee on Banking and Currency On H.R. $7230,75^{\text {th }}$ Cong., $3^{\text {rd }}$ Sess., March, April, U.S. G PO, Washington D.C.

Gup, Benton, 2007, "Corporate Governance in Banks: Does the Board Structure Matter," in Corporate Governance in Banking, (Benton Gup, ed.), Edward Elgar, Cambridge, Cheltenham, UK, pp. 18-39. 
Havrilesky, Thomas 1995, The Pressures on American Monetary Policy, Kluwer Academic Publishers, Boston

. 1991, “The Psychopathology of Monetary Policy,” Contemporary Policy Issues, Vol. 19.

Harding, W. P. G., 1925, The Formative Period of the Federal Reserve System, Constable \& Co., London.

Ickes, Harold, 1953, The Secret Diary of Harold L. Ickes: The Inside Struggle: 1936-1939, Vol. 2, Simon and Schuster, New York.

The Impact of the Federal Reserve System's Monetary Policies on the Nation's Economy, 1976, Staff Report, U.S. House of Representatives, Subcommittee on Domestic Monetary Policy, December.

"Independence, Congressional Weakness and the Importance of Appointment: The Impact of Combining Budgetary Autonomy with Removal Protections," 2012, "Note," Harvard Law Review, Vol. 125, No. 7, May, pp. 1822-43.

Kennedy, Susan E., 1973, The Banking Crisis of 1933, University Press of Kentucky, Lexington, Kentucky.

Kettl, Donald, 1986, Leadership at the Fed, Yale University Press, New Haven, Conn.

Leffingwell, Russell C., 1921, “Discussion,” American Economic Review, March, pp. 30-36.

Link, Arthur, 1956, Wilson, The New Freedom, Princeton University Press, Princeton, New Jersey.

Madeleine, M. Grace, 1943, Monetary and Banking Theories of Jacksonian Democracy, Philadelphia, $\mathrm{Pa}$.

Maisel, Sherman J., 1973, Managing the Dollar, W.W. Norton \& Co., New York.

Mayer, Thomas, 1990, "Introduction," in The Political Economy of American Economic Policy, (Thomas Mayer, ed.), Cambridge University Press, New York

Meltzer, Alan H., 2003, 2009, A History of the Federal Reserve, Vol. I, II, Bk One, Two, The University of Chicago Press, Chicago, Ill.

Meyer, Laurence H., 2004, A Term at the Fed: An Insider's View, Harper Business, New York

Miller, Adolph C., 1921, "Remarks at Joint Conference of the Chairmen and Governors of the Federal Reserve Banks," Washington D. C., Oct. 25-28, 1921, Strong papers, Archives of the Federal Reserve Bank of New York, File No. 212.1.

Mitchell, Wesley Clair, 1913, Business Cycles, University of California Press, Berkeley, California. 
Monks, Robert A.G., and Minow, Nell, 1995, Corporate Governance, Blackwell Business, Cambridge, MA.

National Bank Act, Report, 1926, to accompany H.R. 2, U.S. Senate, Committee on Banking and Currency, U.S. Senate, $69^{\text {th }}$ Cong., $1^{\text {st }}$ Sess., U.S. G.P.O., Washington, D.C., March 25, .

OECD, 2004, Principles of Corporate Governance , "Policy Brief."

Remini, Robert V., 1967, Andrew Jackson and the Bank War, W.W. Norton \& Co., New York.

Report of the Joint Commission of Agricultural Inquiry, 1922, H.R. 408, Part II, $67^{\text {th }}$ Cong., $1^{\text {st }}$ Sess.

Report of the Committee on War Finance, American Economic Association, December, 1918.

Roosa, Robert, 1951, "Interest Rates and the Central Bank," in Money, Trade and Economic Growth; Essays in Honor of J. H. Williams, Macmillan, New York.

Shleifer, Andrei and Robert Vishny, 1997, "A Survey of Corporate Governance, Journal of Finance, 52 (2), pp. 737-83.

Shull, Bernard, 2010, "Too Big to Fail in Financial Crisis: Motives, Countermeasures and Prospects," Working Paper No. 601, Levy Economics Institute.

. 1971, "Report on Research Undertaken in Connection with a System Study," Reappraisal of the Federal Reserve's Discount Mechanism, Vol. 1, Board of Governors of the Federal Reserve System, August, pp. 27-75

. 2005, The Fourth Branch: the Federal Reserve's Unlikely Rise to Power and Influence, Praeger, Westport, Conn.

Shull, Bernard and Kevin Jacques, 1995-96, "Appendix" pp. 227-30 in Shull, "Federal Reserve Independence: What Kind and How Much?," Journal of Post Keynesian Economics, Winter, Vol. 18, No. 2 pp. 211-230.

Schultz, George, Michael Boskin, John Cogan, Allan Meltzer and John Taylor, 2012, "The Magnitude of the Mess We're In," The Wall Street Journal, September 17, p. A19.

Silber, William, 2012, Volcker: The Triumph of Persistence, Bloomsbury Press, New York.

Stabilization, Part 1, 2, 1927, Hearings on H.R. 7895, Bill to Amend Section 14 of the Federal Reserve Act to Provide for the Stabilization of the Price Level for Commodities in 
General, Committee on Banking and Currency, House of Representatives, 69th Congress, 1st Session, U.S. G.P.O., Washington D.C.

Stabilization, 1928, Hearings on H.R. 11806 ( Superseding H. R. 7895), Bill to Amend Section 14 of the Federal Reserve Act to Provide for the Stabilization of the Price Level for Commodities in General, Committee on Banking and Currency, House of Representatives, 70th Congress, 1st Session, U.S. G.P.O., Washington D.C.

Strong to Snyder, "Memorandum," February 28, 1922, Strong Papers, Archives, Federal Reserve Bank of New York.

Strong, Benjamin to W. I. King, "Letter," January 30, 1922, Strong Papers, Archives of Federal Reserve Bank of New York.

U.S. Treasury Department, 1918, Annual Report of the Secretary of the Treasury on the State of Finances for 1917.

Warburg, Paul M.,1930, The Federal Reserve System: Its Origin and Growth, The Macmillan Co, New York.

Weissman, Rudolph L., ed.(1973), Economic Balance and a Balanced Budget, Public Papers of Marriner S. Eccles, DaCapo Press, New York.

Westerfield, Ray B., 1933, “The Banking Act of 1933,” Journal of Political Economy, Vol. 41, Dec. 1933, pp. 721-49.

Wicker, Elmus R., 2005, The Great Debate on Banking Reform, The Ohio State University Press, Columbus, Ohio. . 1966, Federal Reserve Monetary Policy, 1917-1933, Random House, New York, 1966 